\title{
Impact of Essential Oils Blend on Methane Emission, Rumen Fermentation Characteristics and Nutrient Digestibility in Barki Sheep
}

\author{
Mariam G. Ahmed $^{1}$, Samir Z. El-Zarkouny ${ }^{1,2}$, Khaled A. El-Shazly ${ }^{1}$ \& Sobhy M. A. Sallam ${ }^{1}$ \\ ${ }^{1}$ Department of Animal and Fish Production, Faculty of Agriculture, El-Shatby, Alexandria University, Egypt \\ ${ }^{2}$ Arid Land Agriculture Department, Faculty of Meteorology, Environment and Arid Land Agriculture, King \\ Abdulaziz University, Jeddah, Saudi Arabia \\ Correspondence Sobhy M. A. Sallam, Alexandria University, Faculty of Agriculture, Alexandria, El-Shatby \\ 21545, Egypt. Tel: 201-111-003-962. E-mail: s_sallam@yahoo.com
}

Received: March 25, 2014 Accepted: May 4, 2014 Online Published: June 15, 2014

doi:10.5539/jas.v6n7p144 URL: http://dx.doi.org/10.5539/jas.v6n7p144

\begin{abstract}
In vitro and in vivo experiments were conducted to investigate the potential impacts of different levels of essential oils blend (EOB 0, 400, $800 \mu \mathrm{l} / \mathrm{kg}$ of total mixed ration) on total gas and methane production, as well as on rumen fermentation parameters and nutrient utilization. The in vitro assay was carried out using semi-automatic system of gas production (GP) technique. In vivo evaluation was performed using 12 mature male Barki sheep $(39 \pm 3.13 \mathrm{~kg}$ live body weight) randomly allocated into three groups. First group (control, $\mathrm{n}=4$ ) was fed a basal diet, the second group $\left(\mathrm{EOB}_{0.5}, \mathrm{n}=4\right)$ was fed the basal diet supplemented with $0.5 \mathrm{ml}$ of $\mathrm{EOB} / \mathrm{head} / \mathrm{d}$, while the third group $\left(\mathrm{EOB}_{1.0}\right.$, $\mathrm{n}=4$ ) received the basal diet plus $1.0 \mathrm{ml}$ of $E O B / h e a d / d$. The investigation included mixture of commercial essential oils (EO) by equal proprotions e.g., eucalyptus (Eucalyptus globules), cinnamon (Cinnamomum cassia), peppermint (Mentha piperita), thyme (Thymus vulgaris) and lemon (Citrus limon),. The chemical profiles of individual and $\mathrm{EOB}$ were analyzed by GC/MS.

The GC/MS results revealed that the cinnamic aldehyde (100\%), 1,8-cineole (95.0\%), thymol (39.4\%), menthol $(38.6 \%)$ and dl-limonene (88.6\%) were the main components in EOs of cinnamon, eucalyptus, thyme, peppermint and lemon, respectively. There were no significant effects among investigated levels of EOB on in vitro GP and methane production, short chain fatty acids (SCFA), $\mathrm{NH}_{3}-\mathrm{N}$ concentration and protozoa count. The truly degraded organic and dry matter slightly decreased at the highest concentration of EOB tested. In vivo inclusion of $\mathrm{EOB}_{0.5}$ had no significant effect on dry matter intake (DMI) compared to $\mathrm{EOB}_{1.0}$ and untreated animals. Dry and organic matter digestion coefficients were not affected by EOB supplementation, while the digestion coefficients of crude protein $(\mathrm{CP})$ decreased $(\mathrm{P}<0.05)$ with treatments compared to the control group. Supplementation of $\mathrm{EOB}_{0.5}$ increased $(\mathrm{P}>0.05)$ neutral detergent fiber (NDF) digestion compared to $\mathrm{EOB}_{1.0}$ and control group. Acid detergent fiber (ADF) digestion coefficient was not affected by the treatments. Total digestible nutrients (TDN) and digestible crude protein (DCP) were not affected by EOB treatments. There were no significant effects of both doses of $\mathrm{EOB}$ supplementation on N-balance, rumen $\mathrm{pH}, \mathrm{SCFA}$ or $\mathrm{NH}_{3}-\mathrm{N}$ concentration. It can be concluded that $\mathrm{EOB}_{0.5}$ decreased $\mathrm{CP}$ digestion in sheep without positive impacts on other nutrients utilization and ruminal fermentation patterns, which may be related to the additive effects of the combination of $\mathrm{EO}$ and inadequate dose supplementation in the sheep diets.
\end{abstract}

Keywords: methane emission, digestion, nitrogen utilization, rumen fermentation

\section{Introduction}

In ruminants, there are some disadvantages in microbial fermentation in the rumen, which include losses 8 to $12 \%$ of the digestible energy as methane. Furthermore, methane emission into the environment contributes to global warming (Johnson \& Johnson, 1995). Also, 75 to $85 \%$ of the dietary N is excreted in feces and urine (Tamminga, 1992) and has negative impact on the environment by increasing nitrous oxide emissions in the atmosphere (Boadi et al., 2004). Ionophore antibiotics alter rumen fermentation by decreasing deamination of amino acids (Wallace et al., 1990), mitigating methane emission, enhancing feed efficiency (Beauchemin et al., 2008) and reducing diseases disorder such as lactic acidosis (Osborne et al., 2004), and bloat in cattle grazing on legume pastures (Lowe et al., 1991). 
However, the European Union (EU) in the last few years reported that antibiotics used in livestock as production enhancers would be banned from January 2006 (Jouany \& Morgavi, 2007) due to the potential of emergence of residues in milk (Russell \& Houlihan, 2003) and with possible increase of multi drug-resistant bacteria in humans (Manero et al., 2006). Thereafter, EO has been used as a natural alternative to feed antibiotics and growth promoters in livestock (Yang et al., 2010; Sallam et al., 2011). Essential oils (EO) are complex blend of volatile lipophilic secondary metabolites that can be extracting from plants by distillation methods, in particular steam distillation (Greathead, 2003).

Several studies have examined the effects of different individual types of EO e.g peppermint (Agarwal et al., 2009), eucalyptus (Sallam et al., 2009, 2010), thyme (Castillejos et al., 2008) cinnamon (Fraser et al., 2007) and lemon (Castillejos et al., 2006) on ruminal fermentation patterns in vitro. The data showed that EO modified rumen microbial fermentation by decreasing ammonia $\mathrm{N}$ concentration through their impact on hyper-ammonia producing bacteria resulting in reduced deamination of amino acids, reduce methane emission, protozoa count and alter molar ratios of SCFA (Busquet et al., 2006; Agarwal et al., 2009; Sallam et al., 2010, 2011, 2012; Sallam \& Abdalla, 2011; Soltan et al., 2011). Most of the conducted studies on EOB containing thymol, eugenol, vanillin, and limonene noticed that EOB inhibited protein degradation (Molero et al., 2004; Newbold et al., 2004) and reduce methane production (McIntosh et al., 2003).

However, only few studies were conducted in vivo on the EOB. The results showed decreases or unchanged dry matter intake as well as whole tract digestibility (Benchaar et al., 2006, 2007; Santos et al., 2010; Lin et al., 2013). Therefore, we hypothesized that a new blend combining EO by equal proportions will be more beneficial on rumen fermentation characteristics and nutrients utilization. Based on these considerations, this study was undertaken to examine in vitro and in vivo the effects of increasing levels of $\mathrm{EOB}$ supplementation on methane emission, rumen fermentation profiles, feed intake, nutrient digestibility and $\mathrm{N}$ balance of Barki sheep.

\section{Material and Methods}

\subsection{Essential Oils}

Commercial EOB used in the study consisted of equal proportions of eucalyptus (Eucalyptus globules), cinnamon (Cinnamomum cassia), peppermint (Mentha piperita), thyme (Thymus vulgaris) and lemon (Citrus limon), procured from Mady commercial market in Alexandria, Egypt. The chemical profiles of the individual components of eucalyptus, cinnamon, peppermint, thyme, lemon EO and their blend were analyzed by GC/MS (Model HP5890 Ramsey, Minnesota, 55303 USA). The analyses were carried out on GC fitted with a MS capillary column (Model HP 5; 30m, 0.25mmid; $0.25 \mu \mathrm{m}$ thick film). Analytical GC conditions were set to injector temperature $240{ }^{\circ} \mathrm{C}$; oven temperature at $120{ }^{\circ} \mathrm{C}$ for 5 minutes and, then programmed to increase from 120 to $150^{\circ} \mathrm{C}$ at a rate of $5^{\circ} \mathrm{C} / \mathrm{min}$ for $7 \mathrm{~min}$ with helium as carrier gas at a flow rate of $1 \mathrm{ml} / \mathrm{min}$ mass.

\subsection{In vitro Assay}

The EOB was added to the diet sample at different levels $0,400,800 \mu \mathrm{l} / \mathrm{kg}$ of total mixed ration. The total mixed ration was composed of $40 \%$ clover hay and $60 \%$ concentrate mixture, and used as substrate with buffered rumen fluid $(2: 1, \mathrm{v} / \mathrm{v})$ in $120 \mathrm{ml}$ serum bottles for $24 \mathrm{~h}$. The chemical composition of substrate was $911,166,540,214$ and $30.8 \mathrm{~g} \mathrm{~kg}-1$ of organic matter (OM), crude protein (CP), neutral detergent fiber (NDF), acid detergent fiber (ADF) and ether extract (EE), respectively. Three adult rumen-cannulated Barki sheep ( $49.0 \pm 2.3 \mathrm{~kg}$ body weight) were used as inoculum donors. Sheep were fed clover hay ad lib and 750g as-fed of commercial concentrate mixture. The proximate analysis of the concentrate mixture was $89.5,14.5,2.7,38.2$ and $22.6 \%$ for, OM, CP, EE, NDF and ADF, respectively. Both solid and liquid rumen contents $(50: 50 \mathrm{v} / \mathrm{v})$ were collected separately before morning feeding through the cannula using a stainless steel probe $(2.5-\mathrm{mm}$ screen) attached to a large capacity syringe. Liquids and solids were placed in pre-warmed $\left(39^{\circ} \mathrm{C}\right)$ insulated flasks and transported under anaerobic conditions to the laboratory. Pooled rumen contents $(50: 50 \mathrm{v} / \mathrm{v})$ were squeezed through four layers of cheese-cloth and kept in a water bath at $39^{\circ} \mathrm{C}$ with $\mathrm{CO}_{2}$ saturation until inoculation took place. The in vitro gas production (GP) assay was carried out as described by Theodorou et al. (1994) and adapted to the semi-automatic system of Mauricio et al. (1999), using a pressure transducer in $120 \mathrm{ml}$ serum bottles incubated at $39{ }^{\circ} \mathrm{C}$ for $24 \mathrm{~h}$. Ground samples $(0.3 \mathrm{~g}$ as-fed) were incubated in $120 \mathrm{ml}$ serum bottles along with $15 \mathrm{ml}$ mixed rumen fluid and $30 \mathrm{ml}$ of incubation MB9 medium. The composition of MB9 was $\mathrm{NaCl} 2.8 \mathrm{~g} ; \mathrm{CaCl}_{2} 0.1 \mathrm{~g} ; \mathrm{MgSO}_{4} .7 \mathrm{H}_{2} \mathrm{O} 0.1 \mathrm{~g} ; \mathrm{KH}_{2} \mathrm{PO}_{4} 2.0 \mathrm{~g}$ and $\mathrm{Na}_{2} \mathrm{HPO}_{4}$ $6.0 \mathrm{~g}$ per 1.0 litre of distilled water. Then the $\mathrm{pH}$ was adjusted to 6.8 and $\mathrm{CO}_{2}$ was flushed for 30 min (Onodera \& Handerson, 1980).

After filling, bottles were closed with rubber stoppers, shaken and placed in the incubator at $39{ }^{\circ} \mathrm{C}$. The bottles were shaken manually after recording of the gas headspace pressure at 3, 6, 9, 12 and $24 \mathrm{~h}$ incubation using a pressure transducer. The amount of GP at each measuring time was calculated according to the regression equation 
obtained in our system and conditions from unpublished data on 500 samples between gas volume versus pressure. Gas production was calculated by the following equation: $\mathrm{V}=4.97412 \times \mathrm{p}+0.171(\mathrm{n}=500 ; \mathrm{r} 2=0.98$; unpublished data) where: $\mathrm{V}$ is gas volume (ml); $\mathrm{p}$ is measured pressure (psi). Four runs of GP were used for each assay of GP. Measurements of GP were performed in quadruplicate. Each run included four bottles containing buffered rumen fluid without substrate (blank), four bottles containing substrate without additive (control), and four bottles containing substrate for each dose of EOB. The gas values were expressed as $\mathrm{ml}$ per $\mathrm{g}$ of incubated DM.

For methane analyses, the representative gas samples were collected from the bottles by a syringe $(2 \mathrm{ml}$ each time and accumulated in vactutainer tubes, $10 \mathrm{ml}$ ) fifth times at 3, 6, 9, 12, $24 \mathrm{~h}$ incubation. The methane was determined by gas chromatography (Model 7890, Agilent Technologies, Inc, Colorado 80537, USA ) with three valve system using 1/8 inch packed columns having early back flush of the C6 components and equipped with a thermal conductivity detector. Separation was achieved using micro packed column using helium as carrier gas with a flow rate of $28.0 \mathrm{ml} / \mathrm{min}$. The detector and column temperatures were $250{ }^{\circ} \mathrm{C}$ and $60{ }^{\circ} \mathrm{C}$ respectively. The test of linearity and calibration were accomplished using a standard gas curve in the range of probable concentrations of the samples. The methane production at the end of incubation was calculated as described by Tavendale et al. (2005): $\mathrm{CH}_{4}, \mathrm{ml}=$ (total gas volume + headspace) $\times \mathrm{CH}_{4}$ concentration, $\mathrm{ml} / \mathrm{ml}$. After the termination of incubation at $24 \mathrm{~h}$, the contents of two bottles were used for the determination of true digestibility of dry matter (DM) and OM (TDDM, TDOM) according to Blummel and Becker (1997). Another two bottles content were used for determining $\mathrm{NH}_{3}-\mathrm{N}$ (Preston, 1995) and short chain fatty acids (SCFA) concentration (Warner, 1964) in rumen fluid. Protozoa were counted microscopically following the procedure described by Kamra et al. (1991).

\subsection{In vivo Experiment}

\subsubsection{Animals and Diets}

The experiment was conducted during May 2012 at the Milk Production Project, Department of Animal and Fish Production, Faculty of Agriculture, Alexandria University, Egypt. Twelve small Egyptian fat-tailed Barki sheep breed with average live body weight of $39 \pm 3.13 \mathrm{~kg}$ were allocated randomly into three groups based on body weight. The animals were offered separately $750 \mathrm{~g}$ as-fed of both concentrate mixture and clover hay daily. The animals were always treated in accordance with the guidelines of the Internal Commission for Environmental and Ethics in Experimentation with Animals of Alexandria University. The control group received only the basal diet; the second group received the basal diet plus $0.5 \mathrm{ml}$ of $\mathrm{EOB}_{0.5} / \mathrm{head} / \mathrm{d}$ while, the third group received the basal diet plus $1.0 \mathrm{ml}$ of $\mathrm{EOB}_{1.0} / \mathrm{head} / \mathrm{d}$. The $\mathrm{EOB}$ was mixed with concentrate mixture daily. The ingredient and chemical composition of concentrate mixture and clover hay are presented in Table 1. The animals were housed in metabolic crates under a protective roof and had free access to fresh water throughout the study. The clover hay and concentrate mixture were offered twice daily at 08:00 and 16:00h. The experimental period was 30 days, with the first 21 days being used for adaptation to the diet, followed by 7 days of sample collection (feces, urine and, refusal feed) and two final days for rumen fluid sampling via stomach tubes before morning feeding. Individual intakes of clover hay and concentrates were recorded daily by weighing the feed offered and refused. During the collection period, total feces excretion was measured by collecting in bucket for each sheep. Representative sample of feces $\left(10 \%\right.$ of the total quantity) were collected daily from each animal and stored in a refrigerator at $5{ }^{\circ} \mathrm{C}$ throughout collection period. After the trial period, feces samples were mixed thoroughly and one kilogram of this mixture was dried at $60^{\circ} \mathrm{C}$ for $72 \mathrm{~h}$ in a forced drought oven, ground through a $1 \mathrm{~mm}$ screen and stored until analysis. The remainder was kept in a freezer at $-20{ }^{\circ} \mathrm{C}$ for $\mathrm{DM}$ and total $\mathrm{N}$. Urine was collected throughout the day in plastic buckets containing $100 \mathrm{ml}$ of $10 \% \mathrm{H}_{2} \mathrm{SO}_{4}$. Quantity of urine voided in $24 \mathrm{~h}$ was collected, sampled to $(10 \%)$ and stored at $-20^{\circ} \mathrm{C}$. Rumen fluid was collected via stomach tube before morning feeding, and $\mathrm{pH}$ was measured immediately. The rumen fluid was separated from the feed particles through four layers of gauze and stored at $-20{ }^{\circ} \mathrm{C}$ for subsequent analysis.

\subsubsection{Sample Analyses}

Samples analyses were performed according to AOAC (2006) for DM contents of feeds and refusals by drying at $135^{\circ} \mathrm{C}$ for $2 \mathrm{~h}$, and the feces were dried at $105^{\circ} \mathrm{C}$ overnight, OM was determined as the weight loss during ashing at $550{ }^{\circ} \mathrm{C}$ for $2 \mathrm{~h}, \mathrm{~N}$ in feed, refusal, feces and urine were determined by the Kjeldahl method and ether extract (EE) by solvent. NDF and ADF were determined using the procedures of Van Soest et al. (1991). No sodium sulfite or $\alpha$-amylase was used in the procedure for NDF determination. Both NDF and ADF are expressed without residual ash. Concentrations of $\mathrm{NH}_{3}-\mathrm{N}$ (Preston, 1995) and SCFA (Warner, 1964) in rumen fluid were also determined. 


\subsection{Statistical Analysis}

Data were analyzed by the generalized linear model procedure of SAS (2002). The following model was assumed: $\mathrm{Yij}=\mu+\mathrm{Ti}+\mathrm{eij}$ where: $\mu$ is the overall mean, $\mathrm{Ti}$ is the treatment, eij is the random error term. Differences among means were tested using Duncan multiple range test (Steel \& Torrie, 1980).

Table 1. Ingredient and chemical composition of concentrates mixture and clover hay

\begin{tabular}{lcc}
\hline Ingredient composition $(\mathrm{g} / \mathrm{kg})$ & Concentrate mixture & Clover hay \\
\hline Yellow corn & 250 & - \\
Cottonseed meal & 167 & - \\
Wheat bran & 300 & - \\
Sunflower meal & 250 & - \\
$\mathrm{NaCl}$ & 10 & - \\
Limestone & 20 & - \\
Trace minerals* & 3.0 & \\
\hline Chemical composition (\%) & & \\
\hline Ash & 6.11 & 14.24 \\
CP & 14.14 & 15.4 \\
EE & 2.86 & 1.26 \\
NDF & 34.49 & 48.58 \\
ADF & 17.56 & 35.16 \\
\hline
\end{tabular}

OM: organic matter, $\overline{\mathrm{CP}}$ : crude protein; EE: ether extract; NDF: neutral detergent fiber; ADF: acid detergent fiber.*Trace minerals contained $(\mathrm{g} / \mathrm{kg})$ : Manganese Sulphate12.58, Zinc Sulphate 9.3, Copper Sulphate 3.2, Ferrous sulphate 16.67 Calcium iodate 0.081, Sodium selenite 0.4, Magnesium Oxide 9.4, Cobalt Sulphate 0.2, Sodium Chloride Add to Kg. (Dyno Vet Company, Alexandria, Egypt).

\section{Results}

\subsection{Essential Oils Analysis}

Chemical profiles of individual EO and EOB by GC/MS are given in Table 2. The analysis showed difference in the main components in the various oils. The main constituent in the EO of eucalyptus was 1,8-cineole (94.98\%). Thyme EO had 8 components and the most three prevalent being dl-limonene (18.37\%), p-cymene $(23.52 \%)$ and thymol $(39.37 \%)$. Peppermint had higher $\alpha$-pinene $(8.99 \%)$ compared to thyme $(7.19 \%)$, eucalyptus $(2.1 \%)$ and lemon $(0.85 \%)$, where $\alpha$-pinene was not found in cinnamone. Menthol $(38.58 \%)$ was found only in peppermint Lemon had higher dl-limonene of $88.57 \%$ compared to thyme $(18.37 \%)$ and peppermint $(2.39 \%)$, however, dl-limonene was not found in the other EOs. Cinnamic aldehyde was found $100 \%$ only in cinnamon EO. On the other hand, the blend of EOs tended to decrease the concentration of the main bioactive components compared to the individual EO. Cinnamic aldehyde, 1,8-cineole thymol and menthol in EOB were 9.59, 53.52, 1.75 and $14.58 \%$, respectively.

\subsection{In vitro Assay}

Effect of EOB on gas and methane production on TDDM, TDOM, rumen $\mathrm{pH}$, protozoa count, $\mathrm{NH}_{3}-\mathrm{N}$ concentration and SCFA concentration after $24 \mathrm{~h}$ incubation in vitro are shown in Table 3 . The results showed no significant differences in cumulative GP after subtracting the blank gas volume for different levels of EOB. The addition of EOB to the diet did not affect significantly on methane production compared to the control diet. The $\mathrm{DM}$ and $\mathrm{OM}$ degradation and $\mathrm{NH}_{3}-\mathrm{N}$ concentration were decreased insignificantly at higher dose of $\mathrm{EOB}$ in comparison to control. There were no significant differences among investigated levels of EOB on rumen $\mathrm{pH}$, SCFA concentration and protozoa count. 
Table 2. Chemical composition of individual and essential oils blend (\%)

\begin{tabular}{|c|c|c|c|c|c|c|}
\hline & Eucalyptus & Thyme & Peppermint & Lemon & Cinnamon & EOB \\
\hline alpha-Pinene & 2.10 & 7.19 & 8.99 & 0.85 & - & 2.79 \\
\hline beta-Pinene & 0.51 & 2.68 & 4.26 & 0.26 & - & 1.19 \\
\hline beta-Myrcene & 0.43 & - & 0.18 & 1.64 & - & - \\
\hline Phellandrene & 0.23 & - & - & - & - & - \\
\hline 1,8-Cineole & 94.98 & - & - & - & - & 53.52 \\
\hline gamma-Terpinene & 1.20 & - & - & - & - & - \\
\hline 4-Terpineol & 0.13 & - & - & - & - & - \\
\hline alpha-Terpineol & 0.42 & - & - & - & - & - \\
\hline p-Cymene & - & 23.52 & - & - & - & - \\
\hline Cinnamic aldehyde & - & - & - & - & 100.00 & 9.59 \\
\hline dl-limonene & - & 18.37 & 2.39 & 88.57 & - & - \\
\hline Linalool & - & 1.43 & - & - & - & - \\
\hline endo-Borneol & - & 0.72 & - & - & - & - \\
\hline Thymol & - & 39.37 & - & - & - & 1.75 \\
\hline beta-Caryophylle & - & 3.32 & - & - & - & - \\
\hline Camphene & - & - & 0.38 & - & - & - \\
\hline Terpinolene & - & - & 0.37 & - & - & - \\
\hline Isopulegol & - & - & 1.95 & - & - & - \\
\hline Menthone & - & - & 17.35 & - & - & - \\
\hline (+) Isomenthone & - & - & - & - & - & 6.29 \\
\hline neo-menthol & - & - & 15.93 & - & - & \\
\hline Menthol & - & - & 38.58 & - & - & 14.58 \\
\hline$(+)$ Isomenthol & - & - & - & - & - & 5.90 \\
\hline p- Menth-4(8)ene & - & - & - & - & - & 2.01 \\
\hline alpha-terpineol & - & - & 0.95 & - & - & - \\
\hline Pulegone & - & - & 0.96 & - & - & - \\
\hline Pipertone & - & - & 0.59 & - & - & - \\
\hline iso-Menthyl acetate & - & - & 5.35 & - & - & - \\
\hline beta-Bourbonene & - & - & 0.16 & - & - & - \\
\hline Valencene & - & - & 0.13 & - & & - \\
\hline Beta-Caryophyllene & - & - & 0.32 & - & - & - \\
\hline Octanal & - & - & - & 0.33 & - & - \\
\hline Cyclofenchone & - & - & - & 0.26 & - & - \\
\hline alpha-Terpinene & - & - & - & 0.25 & - & - \\
\hline alpha-Humulene & - & - & - & 0.30 & - & - \\
\hline Z-Citral & - & - & - & 2.96 & - & - \\
\hline E-Citral & - & - & - & 3.69 & - & - \\
\hline
\end{tabular}

EOB: essential oils blend. 
Table 3. Effect of essential oils blend (EOB) on gas and methane production, true degradation of dry (TDDM) and organic matter (TDOM), rumen $\mathrm{pH}, \mathrm{NH}_{3}-\mathrm{N}$ concentration, short chain fatty acids (SCFA) concentration and protozoa count after $24 \mathrm{~h}$ incubation in vitro

\begin{tabular}{lccccc}
\hline & \multicolumn{5}{c}{ EOB } \\
\hline & Control & $\mathbf{4 0 0} \boldsymbol{\mu l} / \mathbf{k g}$ diet & $\mathbf{8 0 0} \boldsymbol{\mu l} / \mathbf{k g}$ diet & SEM & P value \\
\hline $\mathrm{GP}(\mathrm{ml} / \mathrm{g} \mathrm{DM})$ & 104.4 & 104.4 & 113.4 & 11.11 & 0.414 \\
$\mathrm{CH}_{4}(\mathrm{ml} / \mathrm{g}$ DOM) & 26.0 & 27.2 & 27.7 & 2.55 & 0.894 \\
$\mathrm{TDDM} \%$ & 65.3 & 65.5 & 63.3 & 8.87 & 0.889 \\
$\mathrm{TDOM} \%$ & 61.7 & 61.8 & 59.3 & 6.88 & 0.774 \\
$\mathrm{Rumen} \mathrm{pH}$ & 61.7 & 6.02 & 6.03 & 0.27 & 0.985 \\
$\mathrm{SCFA}(\mathrm{meq} / 100 \mathrm{ml} \mathrm{BRF})$ & 7.72 & 7.86 & 7.75 & 3.84 & 0.975 \\
$\mathrm{NH}_{3}$-N (mg/100 ml BRF) & 21.5 & 20.8 & 19.19 & 2.44 & 0.461 \\
Protozoa count $\left[\mathrm{x} 10^{5} / \mathrm{ml}\right]$ & 3.6 & 3.3 & 4.0 & 0.98 & 0.529 \\
\hline
\end{tabular}

GP; gas production; SEM: standard error of means; BRF: buffered rumen fluid.

\subsection{In vivo Evaluation}

The effect of EOB supplementation on DM intake (DMI), nutrients digestion coefficients and nutritive value were presented in Table 4. Results showed that the supplementation of EOB did not affect significantly on DMI compared to the untreated animals. The DM and OM digestion coefficients were not affected by both doses of EOB, while the digestion coefficients of $\mathrm{CP}$ decreased significantly $(\mathrm{P}<0.05)$. The inclusion of EOB0.5 showed insignificant increase in NDF digestion coefficient compared to EOB1.0 and control while Acid detergent fiber (ADF) digestion coefficient, TDN and DCP were not affected. Data on the effect of supplementation of EOB on nitrogen balance, rumen $\mathrm{pH}$, SCFA and $\mathrm{NH}_{3}-\mathrm{N}$ are presented in Table 4. Data showed that outputs of $\mathrm{N}$ in feces, urine, and intake were not affected by EOB treatment, resulting in a similar $\mathrm{N}$ balance between EOB supplemented and control. In addition both doses of EOB supplementation had no significant effect on measured rumen $\mathrm{pH}$, SCFA and $\mathrm{NH}_{3}-\mathrm{N}$ concentration.

Table 4. Effect of supplementation of essential oils blend (EOB) on dry matter intake, nutrients digestion coefficients and nutritive value of Barki sheep

\begin{tabular}{|c|c|c|c|c|c|}
\hline \multicolumn{6}{|c|}{ Levels of essential oil blend $(\mathrm{ml} / \mathrm{head} / \mathrm{d})$} \\
\hline & Control & $\mathbf{E O B}_{0.5}$ & EOB $_{1 \cdot 0}$ & SEM & P value \\
\hline DMI (g/d) & 1156.5 & 1106.4 & 1139.8 & 43.1 & 0.142 \\
\hline \multicolumn{6}{|c|}{ Digestion coefficients, $\%$} \\
\hline DM & 71.3 & 71.3 & 69.2 & 2.28 & 0.203 \\
\hline OM & 71.4 & 72.5 & 69.9 & 2.18 & 0.150 \\
\hline $\mathbf{C P}$ & $71.8^{\mathrm{a}}$ & $67.4^{\mathrm{b}}$ & $66.0^{\mathrm{b}}$ & 3.05 & 0.005 \\
\hline NDF & 57.9 & 60.9 & 58.9 & 3.42 & 0.309 \\
\hline ADF & 52.4 & 53.6 & 53.4 & 3.13 & 0.295 \\
\hline \multicolumn{6}{|c|}{ Nutritive value (\%) } \\
\hline TDN & 60.63 & 61.6 & 60.7 & 1.87 & 0.584 \\
\hline DCP & 9.88 & 10.23 & 9.91 & 0.48 & 0.392 \\
\hline
\end{tabular}

Different supescripts $(a, b)$ in the same row indicate significant differences $(p<0.05)$.

$\mathrm{EOB}_{0.5:} 0.5 \mathrm{ml}$ of essential oils blend; EOB ${ }_{1.0}: 1.0 \mathrm{ml}$ of essential oils blend; DMI: dry matter intake; DM: dry matter; OM: organic matter; CP: crude protein; NDF: neutral detergent fiber; ADF: acid detergent fiber, TDN: total digestible nutrients, DCP: digestible crude protein, SEM: standard error of means 
Table 5. Effect of supplementation of essential oils blend (EOB) on nitrogen balance, rumen pH, short chain fatty acids and ammonia $\mathrm{N}$ in Barki sheep

\begin{tabular}{llllll}
\hline \multicolumn{6}{l}{ Levels of blend essential oil (ml/head/d) } \\
\hline & Control & EOB $_{0.5}$ & EOB $_{1 \cdot 0}$ & SEM & P value \\
\hline Nitrogen intake (g/d) & 27.07 & 25.77 & 26.72 & 2.60 & 0.610 \\
Fecal N, g/d & 7.57 & 8.37 & 8.90 & 1.64 & 0.321 \\
Urinary N, g/d & 11.95 & 11.08 & 10.40 & 3.38 & 0.674 \\
Nitrogen balance (g/d) & 15.52 & 16.52 & 16.95 & 5.27 & 0.863 \\
Rumen pH & 6.87 & 6.85 & 6.89 & 0.16 & 0.893 \\
SCF (meq/100ml) & 7.40 & 7.48 & 7.78 & 1.92 & 0.921 \\
$\mathrm{NH}_{3}-\mathrm{N}(\mathrm{mg} / 100 \mathrm{ml})$ & 22.58 & 21.18 & 22.31 & 2.94 & 0.108 \\
\hline
\end{tabular}

$\mathrm{EOB}_{0.5}: 0.5 \mathrm{ml}$ of essential oils blend; EOB ${ }_{1 \cdot 0}: 1.0 \mathrm{ml}$ of essential oils blend; SCFA: short chain fatty acids; SEM: standard error of means.

\section{Discussion}

The analysis of individual or EOB by GC/MS revealed that each type of EO has one or several main compounds (Table 2). In addition, there is some evidence that minor components in EO have a critical part in the biological activity and EO combining may produce additive, synergistic or antagonistic effects among other components (Delaquis et al., 2002). Some new types of EO were detected in EOB e.g. $(+)$ isomenthol, $(+)$ isomenthone and p-menth-4(8)ene. Moreover, dl-limonene was the major component $(88.57 \%)$ in lemon but it disappeared at the EOB, which may be transformed to other isomers of menthols (Croteau et al., 2005). The effects of EO on ruminal fermentation vary with their main components (Busquet et al., 2006). Thus, combining different types of EO or EO components can produce many new types of EO (Bakkali et al., 2008) as reported at the current study. Furthermore, if combining different EO components together can replace natural EOs as additive, existing problems on natural EO such as composition instability, difficulties in collection, and high cost, can be solved. Contrary to our finding regarded methane emission, Lin et al. $(2012,2013)$ found that a balanced combination of EO and EO active components (a mixture of thyme, oregano, cinnamon, and lemon essential oil at an equal ratio, and a mixture of eugenol, carvacrol, citral, and cinnamylaldehyde at an equal ratio) has greater methane reduction ability compared with other combinations. However, that EO are strong inhibitors of methanogenesis in the rumen could be attributed to different types and concentrations of secondary plant metabolites such as terpeniods and phenylpropanoids present in oils (Agarwal et al., 2009; Sallam et al., 2011, 2012; Sallam \& Abdalla, 2011; Soltan et al., 2011). Beauchemin and McGinn (2006) indicated that methane emissions were not affected when beef cattle were fed $1.0 \mathrm{~g} \mathrm{EOB} /$ day, but El-Azark et al. (2011) showed that EOB-containing thyme, cinnamon and peppermint tended to decrease methane emission in vitro. McIntosh et al. (2003) also reported that growth of the methanogen Methanobrevibacter smithii was inhibited at 1,000 ppm of EOB. The difference between these studies may be due to interaction factors related to nutrition and animal, in addition to the dose of EOB and the active components present in the EOB. Also, the lack of response to the supplementation of EOB on methane production in the present study may be attributed to lack of their effect on rumen protozoa count because existence of methanogens has synergism with ruminal protozoa (Bhatta et al., 2012; Goel \& Makkar, 2012). However, McIntosh et al. (2000) and Wallace et al. (2002) demonstrated that the addition of EOB did not affect protozoal numbers or their activity in the rumen, suggesting that the effects were limited to the bacterial population.

Previous studies conducted by dual flow continuous culture system indicated that supplementation of 1.5 (Castillejos et al., 2005) and $5 \mathrm{mg} / \mathrm{l}$ of EOB (Castillejos et al., 2007) increased the concentration of total SCFA without affecting other fermentation parameters. On the contrary, Newbold et al. (2004) and Beauchemin and McGinn (2006) reported that EOB had no effect on SCFA concentration when sheep were fed $110 \mathrm{mg} /$ day or cattle fed $1.0 \mathrm{~g} /$ day. In the present trial, there was no effect of EOB supplementation on $\mathrm{NH}_{3}-\mathrm{N}$ concentration, which is in agreement with results of Castillejos et al. $(2005,2007)$. In contrast, several studies observed that the addition of EOB decreased the effective degradability and the rate of ruminal degradation of some protein supplements (Newbold et al., 2004). Variation in dose and diet composition appeared to be the important difference in the nonconformity of result between different studies. 
In addition, it might be the combination of these five types of EO by equal portions resulted in diluting or decreasing the concentration of the main bioactive components (rumen fermentation modifiers) in each type of EO individually or the dose of EOB used may have been inadequate in the in vitro conditions used in the present experiment.

\subsection{In vivo Experiment}

In vivo studies have been conducted to investigate the effect of EO on feed intake and ruminal and nutrient apparent digestibility, but results are inconsistent (Lin et al., 2013). Santos et al. (2010) observed that supplementation of EO complex (eugenol, geranyl acetate and coriander oil) numerically reduced DMI in lactating dairy cow, which agrees with our result on sheep. Benchaar et al. $(2006,2007 \mathrm{~b})$ noted no change in DMI when lactating dairy cow were supplemented with 200 or $750 \mathrm{mg} / \mathrm{d}$ of EOB including thymol, eugenol, vanillin, guaiacol, and limonene. In contrast, Benchaar et al. (2006); Cardozo et al. (2006); Sallam et al. (2009) and observed that cinnamaldehyde, eucalyptus EO and mix of cinnamaldehyde plus eugenol decreased DMI in lactating dairy cattle, sheep and beef cattle, respectively, which may be related to palatability and odor problems, suggesting that the product needs to be encapsulated to overcome this problem. Recently, Lin et al. (2013) revealed that EO encapsulation was an effective method to solve palatability problems and promote EO acceptance in sheep. In addition, these results indicate that ruminants can endure higher levels of EO than previously thought, and this level would be much higher with encapsulated EO.

Supplementation with EOB did not affect digestibility of DM and OM in the present study, which agrees with the results of some in vivo studies (Santos et al., 2010; Yang et al., 2010; Lin et al., 2013) and in vitro studies by continuous culture fermenters (Castillejos et al., 2005, 2007). Lin et al., 2013 reported that rumen fungi, which is the most important fiber digestion-related microbe in rumen, was not influenced by the addition of EO or active components of EO and therefore the ruminal fiber degradation was not reduced. In contrast, Yang et al. (2007) observed that DM and OM digestibility increased with inclusion of garlic and juniper berry EO in the diet of lactating dairy cows.

A reduced apparent total tract digestibility of CP may be a sign for an increase in bypass protein concentration, however, this additionally means that the potentially produced bypass protein was not digested and absorbed by the animal in the small intestine?! In general apparent total tract digestibility of CP has little explanatory power (Newbold et al., 2004; Molero et al., 2004; Lin et al., 2013). This decrease in CP digestibility could be attributed to the antimicrobial effect of EO on proteolytic bacteria (McIntosh et al., 2003). It appears that EO has many properties including the hydrophobic nature of the cyclic hydrocarbons and the small molecular weight that allows them to penetrate cell membranes (Dorman \& Deans, 2000).

Microbial conversion of peptides and amino acids to ammonia in the rumen is unfavourable to the host animal, because energy is required for microbial protein synthesis, and not all ammonia is incorporated into protein (Wallace et al., 1999). Because of the increasing concern of the role of livestock on climate change, nutritional strategies that aim to decrease $\mathrm{N}$ loss in the rumen are of great interest. At the current study, $\mathrm{NH}_{3}-\mathrm{N}$ concentrations were only slightly affected by EO addition, but the effect is unlikely to be of biological importance. Several authors (Cardozo et al., 2005; Busquet et al., 2006) have reported reductions in ruminal $\mathrm{NH}_{3}-\mathrm{N}$ concentrations due to addition of EO containing cinnamaldehyde and eugenol, but the research was conducted in batch cultures (Cardozo et al., 2005) or continuous culture fermenters (Busquet et al., 2006), maintained under constant $\mathrm{pH}$ conditions.

Some in vitro studies both of long and short term and in vivo studies reported that EO did not affect NDF digestibility as noted in our results (Benchaar et al., 2006; Tassoul \& Shaver, 2009; Santos et al., 2010; Tager \& Krause, 2011). However, Fernandez et al. (1997) observed that sheep given EO from 50 to $1000 \mathrm{mg} /$ day caused a marked inhibition in fiber digestion in the rumen, which may be due to the selective effect of EO on the rumen microbial population (McIntosh et al., 2003). Moreover, Yang et al. (2010) reported that digestibility of NDF linearly decreased with increasing eugenol supplementation at $400,800,600 \mathrm{mg} / \mathrm{d}$ in growing beef cattle. Benchaar et al. (2007a) reported that carvacrol, eugenol and thymol decreased NDF digestibility when added at concentrations of 200, 400, and $800 \mathrm{mg} \mathrm{L}^{-1}$ by in vitro at $24 \mathrm{~h}$. Recently, Lin et al. (2013) reported that the addition of EO combination and active components of EO did not affect apparent total tract digestibility of NDF and ADF but improved NDF and ADF digestibility in the intestines. They concluded that apparent digestibility is a rough index and is usually not sufficient to evaluate effects of EO on nutrient digestion of ruminant digestive tract, and therefore, measurement of ruminal or intestinal digestibility is necessary.

Few studies are available on the effect EOB on N-balance. Benchaar et al. $(2006,2007 \mathrm{~b})$ found no change in $\mathrm{N}$-retention when cows were fed 2.0 and $0.75 \mathrm{~g} / \mathrm{d}$ of the EOB including thymol, eugenol, vanillin, guaiacol, and 
limonene, respectively and these finding are in agreement with our study. The mean values of N-retained due to EOB supplementation were overestimated in thy study of Benchaar et al. (2006). Assuming that the body tissue contains about $20 \%$ protein (NRC, 2001), the retention of $16.5 \mathrm{~g}$ of N/ d (i.e., $103.1 \mathrm{~g}$ of protein/d) should have resulted in a body weight gain of $0.516 \mathrm{~kg} / \mathrm{d}$. Considering the inherent error associated with $\mathrm{N}$ balance studies (Spanghero \& Kowalski, 1997), true N retention was likely overestimated, as illustrated by the modest BW change recorded by Benchaar et al. (2006). In contrast, Sallam et al. (2009) observed that the low level of eucalyptus EO $(10 \mathrm{ml} / \mathrm{d})$ improved $\mathrm{N}$ balance in sheep.

In the current study, the lack of EOB effect on rumen fermentation characteristics may be due to many factors e.g. inadequate dose, chemical composition, roughage concentrate ratio and adaption time as reported previously by Busquet et al. (2006); Cardozo et al. (2004). In addition, our current study suggests that the lack of response of EOB supplementation on rumen fermentation characteristics could be attributed to the use of EO combinations by equal ratios resulted in additive, synergistic or antagonistic effects as mentioned previously by Delaquis et al. (2002).

\section{Conclusion}

This study suggests that the combination of these five types of EO had an additive effect on the chemical profiles of the blend, which may be responsible for the lack response on methane emission; rumen microbial fermentation and apparent total tract digestibility of nutrients expect decreasing the digestibility of $\mathrm{CP}$. Moreover, further investigations using encapsulated higher doses of EO, different EOs profiles and diet composition are required to conclude the potential impacts of EO in ruminants feeding.

\section{Acknowledgement}

The authors gratefully acknowledge the support of this work by the Alex Rep project, Code AGRV-09, 2010-2013, funded by Alexandria University, Egypt.

\section{References}

Agarwal, N., Shekhar, C., Kumar, R., Chaudhary, L. C., \& Kamra, D. N. (2009). Effect of peppermint oil on in vitro methanogensis and fermentation of feed with buffalo rumen liquor. Anim. Feed Sci. Technol., 148, 321-327. http://dx.doi.org/10.1016/j.anifeedsci.2008.04.004

AOAC. (2006). Official Method of Analysis (18th ed.) Association of Analytical Chemists, Gaithersburg, MD, USA.

Bakkali, F., Averbeck, S., Averbeck, D., \& Idaomar, M. (2008). Biological effects of essential oils - a review. Food Chem. Toxicol., 46, 446-475. http://dx.doi.org/10.1016/j.fct.2007.09.106

Beauchemin, K. A., Kreuzer, M., O., Mara, F., \& McAllister, T. A. (2008). Nutritional management for enteric methane abatement: A review. Aust. J. Exp.Agric., 48, 21-27. http://dx.doi.org/10.1071/EA07199

Beauchemin, K. A., \& McGinn, S. M. (2006). Methane emissions from beef cattle: effects of fumaric acid, essential oil, and canola oil. J. Anim. Sci., 84, 1489-1496.

Benchaar, C., Chaves, A. V., Fraser, G. R., Wang, Y., Beauchemin, K. A., \& McAllister, T. A. (2007a). Effects of essential oils and their components on in vitro rumen microbial fermentation. Can. J. Anim. Sci., 87, 413-419. http://dx.doi.org/10.4141/CJAS07012

Benchaar, C., Petit, H. V., Berthiaume, R., Ouellet, D. R., Chiquette, J., \& Chouinard, P. Y. (2007b). Effects of essential oils on digestion, ruminal fermentation, rumen microbial populations, milk production, and milk composition in dairy cows fed alfalfa silage or corn silage. J. Dairy Sci., 90, 886-897. http://dx.doi.org/10.3168/jds.S0022-0302(07)71572-2

Benchaar, C., Petit, H. V., Berthiaume, R., Whyte, T. D., \& Chouinard, P. Y. (2006). Effects of addition of essential oils and monensin premix on digestion, ruminal fermentation, milk production, and milk $\begin{array}{llllll}\text { composition in dairy cows. J. Dairy } & \text { Sci., } & \text { 89, } & \text { 4352-4364. }\end{array}$ http://dx.doi.org/10.3168/jds.S0022-0302(06)72482-1

Bhatta, R., Saravanan, M., Baruah, L., \& Sampath, K. T. (2012). Nutrient content, in vitro ruminal fermentation characteristics and methane reduction potential of tropical tannin-containing leaves. J. Sci. Food Agric., 92, 2929-2935. http://dx.doi.org/10.1002/jsfa.5703

Blummel, M., \& Becker, K. (1997). The degradability characteristics of fifty-four roughages and roughage neutral-detergent fibre as described by in vitro gas production and their relationship to voluntary feed intake. Brit. J Nutr., 77, 757-786. http://dx.doi.org/10.1079/BJN19970073 
Boadi, D., Benchaar, C. Chiquette, J., \& Massé, D. (2004). Mitigation strategies to reduce enteric methane emissions from dairy cows: Update review. Can. J. Anim. Sci., 84, 319-335. http://dx.doi.org/10.4141/ A03-109

Busquet, M., Calsamiglia, S., Ferret, A., \& Kamel. C. (2006). Plant extracts affect in vitro rumen microbial fermentation. J. Dairy Sci., 89, 761-771. http://dx.doi.org/10.3168/jds.S0022-0302(06)72137-3

Cardozo, P. W., Calsamiglia, S., Ferret, A., \& Kamel, C. (2004). Effects of natural plant extracts on ruminal protein degradation and fermentation profiles in continuous culture. J. Anim. Sci., 82, 3230-3236.

Cardozo, P. W., Calsamiglia, S., Ferret, A., \& Kamel, C. (2005). Screening for the effects of natural plant extracts at different $\mathrm{pH}$ on in vitro rumen microbial fermentation of a high-concentrate diet for beef cattle. J. Anim. Sci., 83, 2572-2579.

Cardozo, P. W., Calsamiglia, S., Ferret, A., \& Kamel, C. (2006). Effects of alfalfa extract, anise, capsicum, and a mixture of cinnamaldehyde and eugenol on ruminal fermentation and protein degradation in beef heifers fed a high-concentrate diet. J. Anim. Sci., 84, 2801-2808. http://dx.doi.org/10.2527/jas.2005-593

Castillejos, L., Calsamiglia, S., \& Ferret, A. (2006). Effect of essential oils active compounds on rumen microbial fermentation and nutrient flow in in vitro systems. J. Dairy. Sci., 89, 2649-2658. http://dx.doi.org/10.3168/ jds.S0022-0302(06)72341-4

Castillejos, L., Calsamiglia, S., Ferret, A., \& Losa, R. (2005). Effects of a specific blend of essential oil compounds and the type of diet on rumen microbial fermentation and nutrient flow from a continuous culture system. Anim. Feed Sci. Technol., 119, 29- 41. http://dx.doi.org/10.1016/j.anifeedsci.2004.12.008

Castillejos, L., Calsamiglia, S., Ferret, A., \& Losa, R. (2007). Effects of dose and adaptation time of a specific blend of essential oils compounds on rumen fermentation. Anim. Feed Sci. Technol., 132, 186-201. http://dx.doi.org/10.1016/j.anifeedsci.2006.03.023

Castillejos, L., Calsamiglia, S., Martín-Tereso, J., \& Ter Wijlen, H. (2008). In vitro evaluation of effects of ten essential oils at three doses on ruminal fermentation of high concentrate feedlot-type diets. Animal feed science and technology, 145(1), 259-270. http://dx.doi.org/10.1016/j.anifeedsci.2007.05.037

Croteau, R. B., Davis, E. M., Ringer, K. L, \& Wildung, M. R. (2005). (-) Menthol biosynthesis and molecular genetics. Naturwissenschaften, 92, 562-77. http://dx.doi.org/10.1007/s00114-005-0055-0

Delaquis, P. J., Stanich, K., Girard, B., \& Mazza, G. (2002). Antimicrobial activity of individual and mixed fractions of dill, cilantro, coriander and eucalyptus essential oils. Inter. J. Food Microbiol. 74, 101-109. http://dx.doi.org/10.1016/S0168-1605(01)00734-6

Dorman, H. J. D., \& Deans, S. G. (2000). Antimicrobial agents from plants: Antibacterial activity of plant volatile oils. J. Appl. Microbiol., 88, 308-316. http://dx.doi.org/10.1046/j.1365-2672.2000.00969.x

El-Azrak, K. M., Morsy, A., Soltan, S., Sallam, S. M. A., Samak, M., El-Komy, A., ... Abdalla, A. L. (2011). Effect of specific blend of essential oils on in vitro rumen fermentation and degradability Proc. 22 nd Reunion Latinoam. Production Animal. Oct. 24-26. Montevideo. Uruguay.

Fernandez, M., Serrano, E., Frutos, P., Giraldez, F. J., Mantecon, A. R., \& Llach, J. R. (1997). Effect of Crina HC supplement upon the rumen degradative activity in sheep. Inf. Tech. Econ. Agraria, 18, 160-162.

Fraser, G. R., Chaves, A. V., Wang, Y., McAllister, T. A., Beauchemin, K. A., \& Benchaar, C. (2007). Assessment of the effects of cinnamon leaf oil on rumen microbial fermentation using two continuous culture systems. J. Dairy Sci., 90, 2315-2328. http://dx.doi.org/10.3168/jds.2006-688

Goel, G., \& Makkar, H. P. S. (2012). Methane mitigation from ruminants using tannins and saponins, a status review. Trop Anim Health Prod., 44, 729-739. http://dx.doi.org/10.1007/s11250-011-9966-2

Greathead, H. (2003). Plants and plant extracts for improving animal productivity. P. Nutr. Soc., 62, $279-290$. http://dx.doi.org/10.1079/PNS2002197

Hirasa, K., \& Takemasa, M. (1998). Spice Science Technology. New York: Marcel Dekker, Inc.

Johnson, K. A., \& Johnson, D. E. (1995). Methane emissions from cattle. J. Anim. Sci., 73, 2483-2492.

Jouany, J. P., \& Morgavi, D. P. (2007). Use of natural products as alternatives to antibiotics feed additives in ruminant production. Anim. Cons., 1, 1443-1466. 
Kamra, D. N., Sawal, R. K., Pathak, N. N., Kewalramani, N., \& Agarwal, N. (1991). Diurnal variation in ciliate protozoa in the rumen of blackbuck (Antilope cervicapra). Lett Appl. Microbiol., 13, 165-167. http://dx.doi.org/10.1111/ j.1472-765X.1991.tb00598.x

Lin, B., Lu, Y., Wang, J. H., Liang, Q., \& Liu, J. X. (2012). Effects of combined essential oils along with fumarate on rumen fermentation and methane production in vitro. J. Anim. Feed. Sci., 21, 198-210. http://dx.doi.org/ 10.1016/j.anifeedsci.2013.05.011

Lin, B., Lua, Y., Salem, A. Z. M., Wanga, J. H., Liang, Q., \& Liu, J. X. (2013). Effects of essential oil combinations on sheep ruminal fermentation and digestibility of a diet with fumarate included. Anim. Feed Sci. Technol., 184, 24- 32.

Lowe, L. B., Ball, G. J., Carruthers, V. R., Dobos, R. C., Lynch, G. A., Moate, P. J., ... Valentine, S. C. (1991). Monensin controlled-release intraruminal capsule for control of bloat in pasture dairy cows. Aust. Vet. J., 68 , 17-20. http://dx.doi.org/10.1111/j.1751-0813.1991.tb09834.x

Manero, A., Vilanova. X., Cerda-Cuellar, M., \& Blanch, A. R. (2006). Vancomycin and erythromycin-resistant enterococci in a pig farm and its environment. Environ. Microbiol., 8, 667-674. http://dx.doi.org/10.1111/ j.1462-2920.2005.00945.x

Mauricio, R. M., Mould, F. L., Dhanoa, M. S., Owen, E., Channa, K. S., \& Theodorou, M. K. (1999). A semi-automated in vitro gas production technique for ruminant feedstuff evaluation. Anim. Feed Sci. Technol., 79, 321-330. http://dx.doi.org/10.1016/S0377-8401(99)00033-4

McIntosh, F. M., Newbold, C. J., Losa, R., Williams, P., \& Wallace, R. J. (2000). Effects of essential oils on rumen fermentation. Reprod. Nutr. Dev., 40(Suppl. 2), 221-222 (abstract). http://dx.doi.org/10.1128/ AEM.69.8.5011-5014.2003

McIntosh, F. M.,Williams, P., Losa, R.,Wallace, R. J., Beever, D. A., \& Newbold, C. J. (2003). Effects of essential oils on ruminal microorganisms and their protein metabolism. Appl. Environ. Microbiol., 69, 5011-5014.

Molero, R., Ibara, M., Calsamiglia, S., Ferret, A., \& Losa, R. (2004). Effects of a specific blend of essential oil compounds on dry matter and crude protein degradability in heifers fed diets with different forage to concentrate ratios. Anim. Feed Sci. Technol., 114, 91-104. http://dx.doi.org/10.1016/j.anifeedsci.2003.11.011

National Research Council. (2001). Nutrient Requirements of Dairy Cattle (7th Rev. ed.). Washington, DC: National Academy Press.

Newbold, C. J., McIntosh, F. M.,Williams, P., Losa, R., \& Wallace, R. J. (2004). Effects of a specific blend of essentialoil compounds on rumen fermentation. Anim. Feed Sci. Technol., 114, 105-112. http://dx.doi.org/ 10.1016/j.anifeedsci.2003.12.006

Onodera, R., \& Henderson, C. (1980). Growth factors of bacterial origin for the culture of the rumen oligotrich protozoon, entodinium caudatum. J. Appl. Bacteriol., 48, 125-134. http://dx.doi.org/10.1111/j.1365-2672. 1980.tb05214.x

Osborne, J. K., Mutsvanga, T., Alzahal, O., Duffield, T., Bagg, R., Dick, P., ... McBride, B. W. (2004). Effects of monensin on ruminal forage degradability and total tract diet digestibility in lactating dairy cows during grain-induced subacute ruminal acidosis. J. Dairy Sci., 87, 1840-1847. http://dx.doi.org/10.3168/jds.S00220302(04)73341-X

Preston, T. R. (1995). Biological and chemical analyticalmethods. In T. R. Preston (Ed.), Tropical animal feeding: a manual for research workers (chap. 9, pp. 191-264). Rome: FAO.

Russell, J. B., \& Houlihan, A. J. (2003). Ionophore resistance of ruminal bacteria and its potential impact on human health. FEMS Microbiol. Rev., 27, 65-74. http://dx.doi.org/10.1016/S0168-6445(03)00019-6

Sallam, S. M. A, Bueno, I. C. S., Nasser, M. E., \& Abdalla, A. L. (2010). Effect of eucalyptus (Eucalyptus citriodora) fresh or residue leaves on methane emission in vitro. Ital. J. Anim. Sci., 9, 299-303. http://dx.doi.org/10.1080/1745039X.2011.568275

Sallam, S. M. A, Nasser, M. E. A., Araujo, R. C., \& Abdalla, A. L. (2009). Methane emission in vivo by sheep consuming diet with different levels of eucalyptus essential oil. International symposium on sustainable improvement of animal production and health, 8-11 June 2009, Vienna, Austria.

Sallam, S. M. A., \& Abdalla, A. L. (2011). Antimethanogenic and antiprotozoal effect of some essential oils in vitro. Egy. J. Anim. Prod., 48, 203-215. 
Sallam, S. M. A., Abdelgaleil, S. A. M., Bueno, I. C. S., Nasser, M. E. A., Araujo, R. C., \& Abdalla, A. L. (2011). Effect of some essential oils on in vitro methane emission. Arch. Anim.Nutr., 3, 203-214.

Sallam, S. M. A., Morsy, A. S., Soltan, Y. A., Alencar, S. M., \& Abdalla, A. L. (2012). Antimethanogenic activity of commercial essential oils products. Proc. 14 thInt. seminar of FAO-CIHEAM Sub-Network on sheep \& Goat Nutrition and 2 nd Symp. Low input Breeds. Feeding and management strategies to improve Livestock Productivity, Welfare and product Quality Under Climate Changes. May 15-18, 2012.

Santos, M. B., Robinson, P. H., Williams, P., \& Losa, R. (2010). Effects of addition of an essential oil complex to the diet of lactating dairy cows on whole tract digestion of nutrients and productive performance. Anim. Feed. Sci. Technol., 157, 64-71. http://dx.doi.org/10.1016/j.anifeedsci.2010.02.001

SAS. (2002). SAS users guide statistical analyses systems institute. Cary (NC): SAS.

Soltan, Y. A., Morsy, A. S., Araujo, R. C., Elziat, H. M., Sallam, S. M. A. Louvandini, H., \& Abdalla, A. L. (2011). Carvacrol and eugenol as modifiers of rumen microbial fermentation and methane production in vitro. Proc. Of 4th Animal Wealth Research Conference in the middle East and North Africa (pp. 354-364). Retrieved from http://WWW.Cabdirect.Org

Spanghero, M., \& Kowalski, Z. M. (1997). Critical analysis of N balance experiments with lactating cows. Livestock Prod. Sci., 52, 113-122. http://dx.doi.org/10.1016/S0301-6226(97)00138-3

Steel, R. G. D., \& Torrie, J. H. (1980). Principles and Procedure of Statistics. A Biometrical Approach (2nd ed., pp. 137-269). Mac Graw-Hill Com.

Tager, L. R., \& Krause, K. M. (2011). Effects of essential oils on rumen fermentation, milk production, and feeding behavior in lactating dairy cows. J. Dairy Sci., 94, 2455-2464. http://dx.doi.org/10.3168/ jds.2010-3505

Tamminga, S. (1992). Nutrition management of dairy cows as a contribution to pollution control. J. Dairy Sci. 75, 345-357. http://dx.doi.org/10.3168/jds.S0022-0302(92)77770-4

Tassoul, M. D., \& Shaver, R. D. (2009). Effect of a mixture of supplemental dietary plant essential oils on performance of periparturient and early lactation dairy cows. J. Dairy Sci., 92, 1734-1740. http://dx.doi.org/ $10.3168 /$ jds.2008-1760

Tavendale, M. H., Meagher, L. P., Pacheco, D., Walker, N., Attwood, G. T., \& Sivakumaran, S. (2005). Methane production from in vitro rumen incubations with Lotus pedunculatus and Medicago sativa, and effects of extractable condensed tannin fractions on methanogenesis. Animal Feed Science and Technology, 123, 403-419. http://dx.doi.org/10.1016/j.anifeedsci.2005.04.037

Theodorou, M. K., Williams, B. A., Dhanoa, M. S., McAllan, A. B., \& France, J. (1994). A simple gas production method using a pressure transducer to determine the fermentation kinetics of ruminant feeds. Anim. Feed Sci. Technol., 48, 185-197. http://dx.doi.org/10.1016/0377-8401(94)90171-6

Van Soest, P. J., Robertson, J. B., \& Lewis, B. A. (1991). Methods for dietary fiber, neutral detergent fiber and nonstarch polysaccharides in relation to animal nutrition. J. Dairy Sci., 74, 3583-3597. http://dx.doi.org/ 10.3168/jds.S0022-0302(91)78551-2

Wallace R. J., McEwan, N. R., McIntosh, F. M., Teferedegne, B., \& Newbold, C. J. (2002). Natural products as manipulators of rumen fermentation. Asian-Austr. J. Anim. Sci., 10, 1458-1468. http://dx.doi.org/10.1017/ S0021859600075250

Wallace, R. J., Atasoglu, C., \& Newbold, C. J. (1999). Role of peptides in rumen microbial metabolism review. Asian-Australasian J. Anim. Sci., 12, 139-147.

Wallace, R. J., Newbold, C. J., \& McKein, N. (1990). Influence of ionophores and energy inhibitors on peptides metabolism by rumen bacteria. J. Agric Sci, Cambridge, 115, 285-290.

Warner, E. (1964). Production of volatile fatty acids in the rumen. Methods of measurements. Nutr. Abs. Rev., 34, 339-352.

Yang, W. Z., Benchaar, C., Ametaj, B. N., Chaves, A. V., He, M. L., \& McAllister, T. A. (2007). Effects of garlic and juniper berry essential oils on ruminal fermentation and on the site and extent of digestion in lactating cows. J. Dairy Sci., 90, 5671-5681. http://dx.doi.org/10.3168/jds.2007-0369 
Yang, W. Z., Benchaar, C., Ametajc, B. N., \& Beauchemin, K. A. (2010). Dose response to eugenol supplementation in growing beef cattle: Ruminal fermentation and intestinal digestion. Anim. Feed Sci. Technol., 154, 57-64. http://dx.doi.org/10.1016/j.anifeedsci.2010.03.019

\section{Copyrights}

Copyright for this article is retained by the author(s), with first publication rights granted to the journal.

This is an open-access article distributed under the terms and conditions of the Creative Commons Attribution license (http://creativecommons.org/licenses/by/3.0/). 